\begin{tabular}{|c|c|c|}
\hline 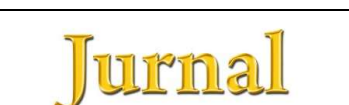 & $\begin{array}{l}\text { Jurnal Penelitian dan Evaluasi Pendidikan } \\
\text { Volume 24, No 1, June } 2020(15-26)\end{array}$ & \\
\hline Peneliftian dan Evaluasi Pendidikan & Online: http://journal.uny.ac.id/index.php/jpep & \\
\hline
\end{tabular}

\title{
AN ANALYSIS OF THE TEACHING PERFORMANCE OF TEACHERS OF ELEMENTARY SCHOOLS IN KUPANG
}

\author{
Lukas Manu $^{1 *}$, Johanis N. Kallau ${ }^{1}$, Paulus Taek ${ }^{1}$, Fredrik Abia Kande ${ }^{2}$ \\ ${ }^{1}$ Department of Social Sciences Education, Universitas Nusa Cendana \\ Jl. Adisucipto Penfui, Lasiana, Klp. Lima, Kota Kupang, Nusa Tenggara Timur 85001, Indonesia \\ ${ }^{2}$ Department of Theology Education, Universitas Tribuana Kalabahi \\ Jl. Soekarno-Hatta, Batunirwala, Kalabahi, Tlk. Mutiara, Alor, Nusa Tenggara Timur 85817, Indonesia \\ *Corresponding Author. E-mail: lukasmanuukaw@gmail.com
}

\begin{abstract}
This research aims to reveal the differences between the performance of bachelor degree holder teachers and that of non-degree holder teachers of elementary schools in Kupang. It applies the survey method. The data were collected using a questionnaire. The questionnaire's validity was measured using the Product Moment Correlation formula, and its reliability was measured using the Alfa Cronbach formula. The data analysis used the non-parametric MannWhitney test with the help of the SPSS Program. The result of the study shows that there is a significant average difference between the teaching performance of bachelor degree holder teachers and that of non-degree holder teachers of elementary schools in Kupang. There is a significant average difference between bachelor degree holder teachers' personality competence and that of non-degree holder teachers. There is a significant average difference between the paedagogic competence of bachelor degree holder teachers and non-degree holder teachers. There is a significant average difference between bachelor degree holder teachers' social competence and that of non-degree holder teachers. Therefore, it is suggested that non-degree holder teachers keep improving their academic qualification and work performance through varieties of self-development efforts.
\end{abstract}

Keywords: bachelor-degree holder teacher, non-degree holder teacher, teaching performance

How to cite: Manu, L., Kallau, J., Taek, P., \& Kande, F. (2020). An analysis of the teaching performance of teachers of elementary schools in Kupang. Jurnal Penelitian dan Evaluasi Pendidikan, 24(1), 15-26. doi:https://doi.org/10.21831/pep.v24i1.25590

\section{INTRODUCTION}

Law of Republic of Indonesia No. 20 of 2003 on National Education System, article 39, paragraph 2 states that "Educators are professionals who have the duty to plan and implement learning processes, assess education outcomes, carry out counseling and training, and conduct research and community service, especially for higher education institution personnel." As a professional, teachers need to have various competencies to enable them to do their job.

For teachers, in particular, those competencies are developed through both formal education in teachers' colleges (LPTK or Lembaga Pendidikan Tenaga Kependidikan (Teachers Educational Institution)) and professional development programs. Equipped with those competencies, teachers are expected to be skillful at carrying out their optimal teaching performance.

Law No. 14 of 2005 of Republic of Indonesia about Teachers and Lecturers; Regulation of the Minister of National Education No. 19 of 2005 on National Standard of Education; and Regulation of the Minister of National Education No. 16 of 2007, on the Standard of Teachers' Academic Qualification and Competence regulate academic qualification standards and teacher competencies, stating that in terms of academic qualification, teachers are bache- 
16 - Lukas Manu, Johanis N. Kallau, Paulus Taek, \& Fredrik Abia Kande

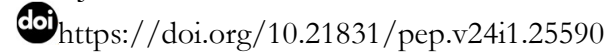

lor degree holders (Strata One or S1) and/or graduate diploma holders (Diploma Four or D4) who have personal, pedagogic, professional, and social competencies.

The requirement for those academic qualifications does not apply to non-degree holder teachers in various levels of education, although they have carried out their professional duties. The requirement for the academic qualification of teachers being at minimum bachelor degree (S1) or D4 is meant to develop working competence and performance so that teachers are able to do their job professionally. In reality, however, not all teachers are bachelor-degree holders. There are still many non-degree holder teachers. Of course, the latter is considered not fulfilling the requirement stated in the regulations.

The data on the national distribution of academically qualified teachers of S1/D4 at minimum or bachelor degree holder teachers and non-degree holder teachers in every province/regency/city are highly varied, particularly when it is related to the needs in each region. In reality, this is problematic, and it can affect educational quality because low academic qualification causes low competence and working performance, which in turn will lower student quality and educational quality in general.

This study focuses on Nusa Tenggara Timur (NTT) Province, especially Kupang City, as the capital city of NTT Province. The subjects are the teachers of elementary schools in the city. The number of teachers in $2010 / 2011$ is 2,743 spread in every formal education level (Office of Education, Youth, 2010). The number of elementary school teachers is 1,919, out of which 1,389 teachers or $70.54 \%$ have not met the academic qualification requirement, and they are spread in 123 elementary schools. Of course, this figure of $1.389(70.54 \%)$ is not small. The number even outnumbers the teachers whose academic qualification is at least a bachelor's degree (S1).

The teacher portrait with this fantastic number can cause pessimism in realizing professional teachers. The efforts to realize professional teachers as the prerequisite to create quality education seem to be a mission impossible. There is a lack of assurance in creating quality and competitive education in the future.

For this reason, in order to trigger the fulfillment of teachers' academic qualifications and competence, the government, through Badan Standar Nasional Pendidikan (BSNP) or the Board of National Education Standards, manages teacher certification programs followed by a number of teachers in Kupang City. Since 2008, most of the teachers who have met the academic qualification of S1/D4 have been given the opportunity to be certified and to get a professional allowance. This has encouraged the teachers who have not met the requirement to fulfill that requirement. That is why there is no reason for the teachers not to improve their academic qualification as well as their work performance because the academic qualification that meets the requirement will guarantee high work performance that contributes to the improved quality of teaching, which in turn will affect student quality.

The standard of the work performance of the teachers of elementary schools is regulated in the Regulation of the Minister of National Education No. 16 of 2007, on the Standard of Teachers' Academic Qualification and Competence, in which teacher competencies are developed holistically from four principle competencies: pedagogic, personal, social, and professional competencies. The four competencies are integrated into teacher performance. Thus, in this research, teacher performance refers to the four teacher competencies.

Research on the work performance of the teachers of elementary schools in Kupang is getting more and more urgent when it is related to student achievement in National Standard School Examination, which in the last three years showed a fluctuating trend, or did not show a high static trend. This is highly related to teacher competence and teaching performance.

In addition, teaching activities which are generally product-oriented are the reason for the teachers' work performance, which becomes not optimal. The lack of supervision worsens this situation. For this reason, the researchers are encouraged to conduct a study related to the 
work performance of elementary school teachers who are bachelor-degree holders and nondegree holder teachers in Kupang City.

The related studies ever conducted include the study by Pramantik and Pardjono (2016) on the professionalism of the teachers of special education in Yogyakarta Special Region, which found that in terms of pedagogic competence, all respondents made lesson plans. In terms of personal competence, all respondents show attitude as exemplary persons, discipline, and sincere work. In terms of social competence, some respondents manifest it in a non-discriminated attitude, while other respondents realized it by playing a more active role in the activities in their community. In terms of professional competence, all respondents showed it by learning continually, participating in workshops and training, and writing books in teaching development. The difference between this study and the study by Pramantik and Pardjono (2016) lies in the emphasis. The study by Pramantik and Pardjono (2016) focuses only on four principle competencies, while this study is not limited to four competencies; it also covers performance. Besides, in relation to the research subjects, this study involves both bachelor's degree holder teachers and non-degree holder teachers.

Another study by Muthmainnah and Marsigit (2018) on the teaching styles of beginner teachers and professional teachers in teaching mathematics in junior high schools in Klaten found that, in general, beginner teachers and professional teachers in the process of teaching mathematics used the same teaching style but in different portions. Professional teachers used six teaching styles with the tendency of using the teaching style of practical work. In contrast, beginner teachers are not very capable of using the teaching style of practical work. Beginner teachers used five teaching styles with the tendency of using the teaching style of practice and inclusion. The study by Muthmainnah and Marsigit (2018) is different from this study that their study focuses on teaching style while this study focuses on competence and performance.

Another related study, the one by Sabon (2017) about students' perception of the competence of the teachers who have and have not been certified, reported that in both state and private elementary schools, the students perceived that the competence of the teachers who have been certified is better that that of those who have not been certified. In state and private junior high schools, the competence of the teachers who have not been certified is better than that of those who have been certified. While Sabon's study viewed teachers' competence based on students' perception, this study reveals holistically based on the evaluation of the aspects of teachers' performance and competence stated by BSNP in the form of the Guideline of the Implementation of Teachers' Performance Evaluation.

Therefore, this study aims to compare: (1) the performance of bachelor degree holder teachers and non-degree holder teachers of elementary schools in Kupang, (2) the professional competence of bachelor degree holder teachers and non-degree holder teachers of elementary schools in Kupang, (3) the personal competence and bachelor degree holder teachers and non-degree holder teachers of elementary schools in Kupang, (4) the pedagogic competence of bachelor degree holder teachers and non-degree holder teachers of elementary schools in Kupang, and (5) the social competence of bachelor degree holder teachers and non-degree holder teachers of elementary schools in Kupang.

\section{RESEARCH METHOD}

This research is a survey in search of the differences between the performance of bachelor degree holder teachers and that of non-degree holder teachers of elementary schools in Kupang. It has one variable, i.e., performance, and a sub-variable, i.e., competence.

This research population is 1,919 bachelor degree holder and non-degree holder teachers of elementary schools in Kupang, consisting of 550 bachelor degree holder teachers and 1,349 non-degree holder teachers. A sample of 135 teachers consisting of 95 bachelor degree holder teachers and 40 non-degree holder teachers was established randomly. 
The data were collected using a questionnaire distributed to the teachers. The questionnaire was constructed by referring to the aspects of teachers' performance and competence stated by the BSNP through the Directorate of Teacher Profession and Directorate General of Quality Improvement of Teachers and Educational Personnel in the Department of National Education in the form of Guideline of the Implementation of Teacher Performance Evaluation. The instrument grid is presented in Table 1.

Table 1. Research Instrument Grid

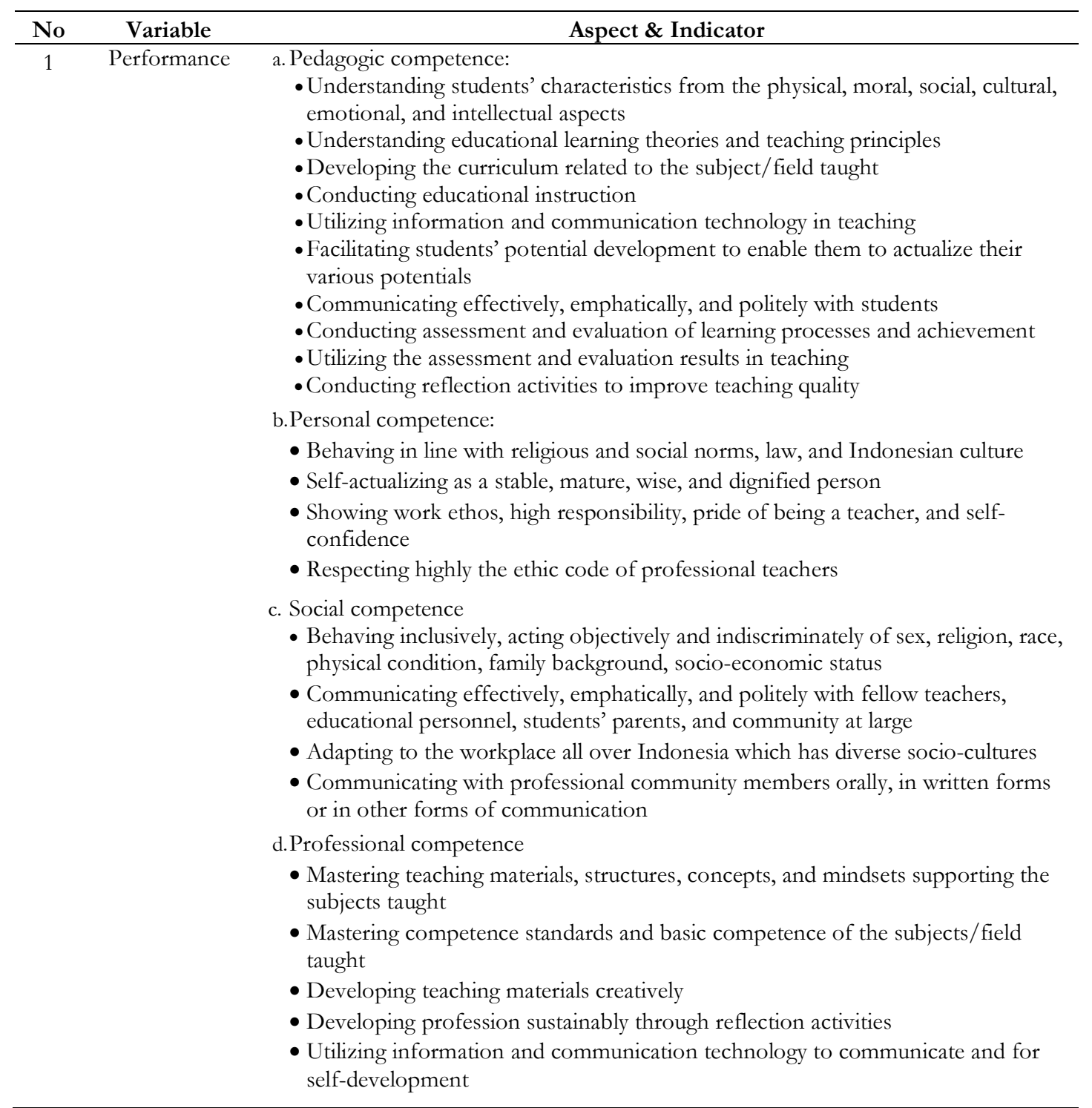

After the questionnaire consisting of 175 items was constructed by referring to the grid, it was tried out to 88 teacher respondents. Based on the SPSS calculation, 158 items were valid, and the rest 17 items were invalid and thus dropped. Furthermore, the valid data were measured for their reliability. Since the questionnaire is polytomous, the reliability test used the Alpha Cronbach formula with SPSS. The number of items before the validity test was 175 items. After the validation, 17 items were dropped; thus, the number of items to be measured for their reliability was 158 items. The basic value of Cronbach's Alpha is $>0.60$ (Sujarweni, 2014, p. 193). 
Based on the calculation result, the Cronbach's Alpha value of 158 items is $>0.60$. It indicates that the 158 statements have high reliability. The analysis technique used is the nonparametric Mann-Whitney Test with the help of the SPSS Program because the data normality assumption is not fulfilled, in this case, the data on the performance of bachelor degree holder teachers and non-degree holder teachers of elementary schools in Kupang.

\section{FINDINGS AND DISCUSSION}

The Differences between the Performance of Bachelor Degree Holder Teachers and that of Non-Degree Holder Teachers of Elementary Schools in Kupang

Performance in this study is meant to be teachers' competencies, including professional competence, personal competence, pedagogic competence, and social competence. For the sake of testing the data related to teachers' performance, the hypothesis is formulated as follows. Meanwhile, the results of the test using SPSS Program are shown in Table 2 and Table 3.

$\mathrm{H}_{\mathrm{o}}=$ There is no average difference between the performance of bachelor degree holder teachers and that of non-degree holder teachers.

$\mathrm{H}_{\mathrm{a}}=$ There is an average difference between the performance of bachelor degree holder teachers and that of non-degree holder teachers.

Table 2. Average Scores of Performance of Teachers in Kupang

\begin{tabular}{lccccc}
\hline & \multicolumn{2}{c}{ Ranks } & & \\
\cline { 2 - 6 } & & Qualification & N & Mean Rank & Sum of Rank \\
\hline Degree of performance & Bachelor & 95 & 86.27 & 6296.00 \\
& & Non-degree holder & 40 & 62.10 & 2884.00 \\
& & & 135 & & \\
\hline
\end{tabular}

Table 3. Performance of Bachelor Degree Holder Teachers and Non-Degree Holder Teachers of Elementary Schools in Kupang

\begin{tabular}{lc}
\hline & Test Statistics $^{\mathbf{a}}$ \\
\cline { 2 - 2 } & \\
\hline Mann-Wbitney $U$ & Performance Level \\
Wilcoxon $W$ & 1736.000 \\
$Z$ & 6296.000 \\
Asymp. Sig. (2-tailed) & -.190 \\
\hline
\end{tabular}

a. Grouping Variable: Academic Qualification

Overall, the performance of bachelor degree holder teachers is better than that of the non-degree holder teachers. It is shown by the higher mean score of bachelor degree holder teachers compared to that of the non-degree holder teachers $(86.27>62.10)$.

\section{The Differences between the Professional Competence of Bachelor Degree Holder Teachers and that of Non-Degree Holder Teachers of Elementary Schools in Kupang}

For the sake of testing the data, the hypothesis is formulated as follows. Meanwhile, the results of the hypothesis testing using the SPSS Program are presented in Table 4 and Table 5.

$\mathrm{H}_{\mathrm{o}}=$ There is no average difference in the level of professional competence between bachelor degree holder teachers and non-degree holder teachers.

$\mathrm{H}_{\mathrm{a}}=$ There is an average difference in the level of professional competence between bachelor degree holder teachers and non-degree holder teachers. 
Table 4. Calculation Result of the Average Professional Competence of Teachers of Elementary Schools in Kupang

\begin{tabular}{lcccc}
\hline & \multicolumn{2}{c}{ Ranks } & & \\
\cline { 2 - 5 } & Group & N & Mean Rank & Sum of Rank \\
\hline Professional competence & Bachelor degree hoder teachers & 95 & 87.85 & 6445.50 \\
& Non-degree holder teachers & 40 & 68.36 & 2734.50 \\
& Total & 135 & & \\
\hline
\end{tabular}

Table 5. Significance Testing Result of Professional Competence of Teachers of Elementary Schools in Kupang

\begin{tabular}{lc}
\hline & Test Statistics $^{\mathbf{a}}$ \\
\cline { 2 - 2 } & \\
\hline Mann-Whitney $U$ & Professional Competence \\
Wilcoxon $W$ & 1885.500 \\
$Z$ & 6445.500 \\
Asymp. Sig. (2-tailed) & -.070 \\
\hline
\end{tabular}

a. Grouping Variable: Academic Qualification

The professional competence of bachelor degree holder teachers is higher than that of non-degree holder teachers. It is indicated by the higher mean score of bachelor degree holder teachers compared to that of the non-degree holder teachers $(87.85>68.36)$.

The Differences between the Personal Competence of Bachelor Degree Holder Teachers and that of Non-Degree Holder Teachers of Elementary Schools in Kupang

For the sake of testing the data, the hypothesis is formulated as follows. Meanwhile, the results of the hypothesis testing using the SPSS Program are presented in Table 6 and Table 7.

$\mathrm{H}_{\mathrm{o}}=$ There is no average difference in the level of personal competence between bachelor degree holder teachers and non-degree holder teachers.

$\mathrm{H}_{\mathrm{a}}=$ There is an average difference in the level of personal competence between bachelor degree holder teachers and non-degree holder teachers.

Table 6. The Result of Calculating the Average Personal Competence of Teachers of Elementary Schools in Kupang

\begin{tabular}{lcccc}
\hline & \multicolumn{2}{c}{ Ranks } & & \\
\cline { 2 - 5 } & Group & N & Mean Rank & Sum of Rank \\
\hline Personal competence & Bachelor degree holder teachers & 95 & 86.40 & 6308.00 \\
& Non-degree holder teachers & 40 & 71.80 & 2872.00 \\
& Total & 135 & & \\
\hline
\end{tabular}

Table 7. Significance Testing Result of Personal Competence of Teachers of Elementary Schools in Kupang

\begin{tabular}{|c|c|}
\hline \multicolumn{2}{|c|}{ Test Statistics ${ }^{\mathrm{a}}$} \\
\hline & Personal Competence \\
\hline$\overline{M a n n-W h i t n e y ~} U$ & 1748.000 \\
\hline Wilcoxon $W$ & 6308.000 \\
\hline$Z$ & -.733 \\
\hline Asymp. Sig. (2-tailed) & .463 \\
\hline
\end{tabular}


The personal competence of bachelor degree holder teachers is higher than those nondegree holders, indicated by the higher mean score of bachelor degree holder teachers compared to the non-degree holder teachers $(86.40>71.80)$.

\section{Differences between the Pedagogic Competence of Bachelor Degree Holder Teachers and that of Non-Degree Holder Teachers of Elementary Schools in Kupang}

For testing the data, the hypothesis is formulated as follows. The hypothesis testing results using SPSS Program are presented in Table 8 and Table 9.

$\mathrm{H}_{\mathrm{o}}=$ There is no average difference in the level of pedagogic competence between bachelor degree holder teachers and non-degree holder teachers.

$\mathrm{H}_{\mathrm{a}}=$ There is an average difference in the level of pedagogic competence between bachelor degree holder teachers and non-degree holder teachers.

Table 8. The Result of Calculating the Average Pedagogic Competence of Teachers of Elementary Schools in Kupang

\begin{tabular}{lcccc}
\hline & \multicolumn{2}{c}{ Ranks } & & \\
\cline { 2 - 5 } & Group & N & Mean Rank & Sum of Rank \\
\hline Pedagogic competence & Bachelor degree holder teachers & 95 & 86.90 & 6355.50 \\
& Non-degree holder teachers & 40 & 70.61 & 2824.50 \\
& Total & 135 & & \\
\hline
\end{tabular}

Table 9. Significance Testing Result of Pedagogic Competence of Teachers of Elementary Schools in Kupang

\begin{tabular}{lc}
\hline & Test Statistics $^{\mathbf{a}}$ \\
\cline { 2 - 2 } & \\
\hline Mann-Whitney $U$ & Pedagogic Competence \\
Wilcoxon $W$ & 1795.500 \\
$Z$ & 6355.500 \\
Asymp. Sig. (2-tailed) & -.504 \\
\hline
\end{tabular}

a. Grouping Variable: Academic Qualification

From Table 8 and Table 9, it is known that the pedagogic competence of bachelor degree holder teachers is higher than that of non-degree holder teachers. It is indicated by the higher mean score of bachelor degree holder teachers compared to that of the non-degree holder teachers $(86.90>70.61)$.

\section{Differences between the Social Competence of Bachelor Degree Holder Teachers and that of Non-Degree Holder Teachers of Elementary Schools in Kupang}

For testing the data, the hypothesis is formulated as follows. Meanwhile, the results of the hypothesis testing using the SPSS Program are presented in Table 10 and Table 11.

From Table 10 and Table 11, it is clear that the social competence of bachelor degree holder teachers is higher than that of non-degree holder teachers. It is indicated by the higher mean score of bachelor degree holder teachers compared to that of the non-degree holder teachers $(84.51>74.78)$.

$\mathrm{H}_{\mathrm{o}}=$ There is no average difference in the level of social competence between bachelor degree holder teachers and non-degree holder teachers.

$\mathrm{H}_{\mathrm{a}}=$ There is an average difference in the level of social competence between bachelor degree holder teachers and non-degree holder teachers. 
22 - Lukas Manu, Johanis N. Kallau, Paulus Taek, \& Fredrik Abia Kande

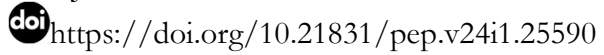

Table 10. Calculation Result of the Average Social Competence of Teachers of Elementary Schools in Kupang

\begin{tabular}{lcccc}
\hline & \multicolumn{2}{c}{ Ranks } & & \\
\cline { 2 - 5 } & Group & N & Mean Rank & Sum of Rank \\
\hline Pedagogic competence & Bachelor degree holder teachers & 95 & 84.51 & 6128.50 \\
& Non-degree holder teachers & 40 & 74.78 & 2916.50 \\
& Total & 135 & & \\
\hline
\end{tabular}

Table 11. Significance Testing Result of Social Competence of Teachers of Elementary Schools in Kupang

\begin{tabular}{|c|c|}
\hline \multicolumn{2}{|c|}{ Test Statistics $^{a}$} \\
\hline & Pedagogic Competence \\
\hline Mann-Whitney $U$ & 1568.500 \\
\hline Wilcoxon $W$ & 6128.500 \\
\hline$Z$ & -1.392 \\
\hline Asymp. Sig. (2-tailed) & .164 \\
\hline
\end{tabular}

a. Grouping Variable: Academic Qualification

Based on the findings, it can be described that teacher performance is the teacher's overall achievement in a certain period of time, which can be measured based on competence indicators and commitment to work accomplishment. According to Robbins (2001, p. 241), performance is the function $(\mathrm{f})$ of interaction between competence $(\mathrm{A})$ and motivation $(\mathrm{M})$, i.e., performance $=\mathrm{f}(\mathrm{A} \times \mathrm{M})$. Commitment and motivation used in this theory are actually contained in the competencies required from teachers, especially for personal competence and social competence.

This study did not find any significant difference in relation to overall performance between bachelor degree holder teachers and non-degree holder teachers of elementary schools in Kupang. The performance of bachelor degree holder teachers is better than that of the non-degree holder teachers, as shown by the higher mean score of bachelor degree holder teachers compared to that of the non-degree holder teachers $(86.27>62.10)$, but the difference is not significant.

This finding is not in line with those of other studies, which showed that the performance of most professional teachers (certified teachers) in Sleman Regency was not good; out of the 17 indicators understudy, seven indicators were good, and ten other indicators were not good (Kartowagiran, 2011). Although the study by Kartowagiran did not use the sample of teachers with bachelor qualifications, certified teachers must be those who have met all the requirements of a bachelor degree holder.

Another study reported that the factors of knowledge, skill, and motivation simultaneously contributed as much as $20.5 \%$ to mathematics teacher performance, and the other $79.5 \%$ was affected by other factors (Indrawati, 2006). The performance factor stated through pedagogic, professional, personal, and social competencies plays a very important role in improving teaching and student qualities. As the study by Astuti and Dacholfany (2016) reported, there is a positive effect of supervision by school supervisors and principal's leadership on teacher performance. This finding stated that performance factors are related to other factors such as leadership and supervision.

The researchers are aware that there are other factors that make teacher performance low, as a study by Tao (2013) reported that teachers are respectable human beings so that for their high achievement in competence and performance the aspect of reward must be given proper attention, especially by the principal and education supervisor. If this factor is ne- 
glected, teachers will show deficiency behavior, that is, making the least effort and showing apathy to various demands addressed to them even though they have met the academic qualification requirement. The study by Jeong and Luschei (2018) reported that although the teachers' level of education increased, their responsibility decreased.

Academic qualification is expected to be the determining factor that determines better teacher performance. The higher the teachers' academic qualification, the higher their knowledge and teaching skill, as well as their mastery of theories, will be.

In relation to the professional competence of bachelor degree holder teachers and nondegree holder teachers of elementary schools in Kupang, the findings show significant average differences between the professional competence of bachelor degree holder teachers and that of non-degree holder teachers of elementary schools in Kupang. The competence of bachelor degree holder teachers is higher than that of non-degree holder teachers, as indicated by the higher mean score of bachelor degree holder teachers compared to that of the non-degree holder teachers $(87.85>68.36)$, but it is not significant.

This finding is not easy to understand because it cannot be accepted as an appropriate condition since it is a must for bachelor degree holder teachers to have much higher professional competence compared to that of non-degree holder teachers. Only with high competence can teachers improve their performance.

High performance is needed in order to maximize teachers' professional work. High performance results from good competence. This is in line with the study by Setyono and Sudjadi (2011), which reported that teacher competence has a positive effect on teacher performance. This means that if teacher competence is improved, teacher performance will also be improved.

The study by Abbas (2013) also reported that teacher competence is an instrument that can give school improved services to students through teacher performance. Good teacher competence will have a positive effect on the implementation of various functions and duties of the teacher. This finding reveals that teachers' professional competence is the factor affecting the overall performance of teachers.

In relation to teachers' personal competence, the research finding shows that there is an average difference in the level of personal competence between bachelor degree holder teachers and non-degree holder teachers of elementary schools in Kupang. The performance of bachelor degree holder teachers is higher than that of non-degree holder teachers, as indicated by the higher mean score of bachelor degree holder teachers compared to that of non-degree holder teachers $(86.40>71.80)$.

The personal competence of the teachers of elementary schools can be seen in the abilities, including the ability to act in line with religious and social norms, law, and Indonesian national culture; the ability to be a stable, mature, wise, and dignified person; the ability to show work ethos, high responsibility, the pride of being a teacher, and self-confidence; and the ability to highly respect teacher professional ethic.

The aforementioned points should be shown by teachers, especially bachelor degree holder teachers, who are expected to be better and can become model teachers. Empirically, they can give justification for the value of formal requirements related to academic qualification, and even there is a logical relation between teachers' academic qualification and their competence.

A teacher's personal competence is very important and necessary, especially considering various demands and development, particularly the development of students who need teachers who are stable and mature and behave according to norms, and thus can be a model for students. This is in line with a study that reported that there is a significant positive effect of teacher competence, principal leadership, teacher work motivation, partially and simultaneously, and directly and indirectly (Susanto, 2012). 
In relation to teacher pedagogic competence, this research finding shows that there is a significant average difference between the competence of bachelor degree holder teachers and that of non-degree holder teachers of elementary schools in Kupang. Overall, the pedagogic competence of bachelor degree holder teachers is higher than that of non-degree holder teachers, as indicated by the higher mean score of bachelor degree holder teachers compared to that of the non-degree holder teachers $(86.90>70.61)$.

The pedagogic competence of elementary school teachers can be seen in the abilities such as understanding students' characteristics from the physical, moral, social, cultural, emotional, and intellectual aspects; understanding educational learning theories and teaching principles; developing the curriculum related to the subject/field taught; conducting educational instruction; utilizing information and communication technology in teaching; and so on. Teachers should be able to demonstrate those abilities, especially for bachelor degree holder teachers, it is imperative that they do perform those abilities. The bachelor's degree holder teachers are aware that they have met the standard academic qualification, and thus they have to be competent too.

High pedagogic competence, especially of bachelor degree holder teachers, should obviously reflect positive indicators. Despite this, it is understood that pedagogic competence, as well as other competencies, does not stand alone. This is in line with a study that reported that (1) there is a significant effect of supervision to classrooms by principals on teachers' performance; (2) there is a significant effect of compensation on teachers' performance; and (3) simultaneously, there is a significant effect of supervision to classrooms by principals on teachers' performance and compensation on teachers' performance (Brotosedjati, 2012). That is why teachers need to maximize every required competency in order to achieve maximum performance. When teachers can maximize their competencies, and school principals and supervisors give full supports, maximum performance will result, and student quality will improve.

As another study proved, there is a direct effect of teachers' competence on senior high school students' achievement in economics subjects Inayah et al. (2013). According to the Ministry of Research, Technology, and Higher Education of Republic of Indonesia (2010), competence is the ability needed to do something based on knowledge, skill, and attitude. Therefore, competence is a set of abilities that should be demonstrated by teachers in doing their professional duties.

In relation to teachers' social competence, the finding of this study shows that there is an average difference in the level of social competence between bachelor degree holder teachers and non-degree holder teachers of elementary schools in Kupang. The social competence of bachelor degree holder teachers is higher than that of non-degree holder teachers, as indicated by the higher mean score of bachelor degree holder teachers compared to that of the non-degree holder teachers $(84.51>74.78)$.

The social competence of elementary school teachers can be seen from their abilities in such activities as behaving inclusively; acting objectively and indiscriminately of sex, religion, race, physical condition, family background, socio-economic status; communicating effectively, emphatically, and politely with fellow teachers, educational personnel, students' parents, and the community at large; adapting to the workplace all over Indonesia which has diverse socio-cultures; communicating with professional community members orally, in written forms or in other forms of communication.

Social competence requires teachers to be competent at maintaining relations with everyone wherever they are. The perspective that can be put forward is schools, and the community in which the teachers are in are the social environment that relies on good interaction and interrelation from all parties, including teachers, who are required to have positive interaction and interrelation with all parties. Positive interaction and interrelation will create an oasis for teachers so that they will be more active in doing their professional work, educating students wherever they are assigned to. 
25 - Lukas Manu, Johanis N. Kallau, Paulus Taek, \& Fredrik Abia Kande

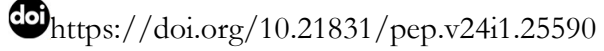

What teachers need to know is that the tendency to be satisfied with the knowledge they have got must be avoided. They must encourage themselves to do much reading, thinking, writing, and exercising, and later to do much talking. Teachers' desire and interest to do much reading is the indication of personality because it shows the work ethos of the scientific man.

Elementary school teachers need to improve their abilities and motivation to achieve high quality. In this case, a deep and holistic understanding of anything related to their work is of prime importance. The study by Eros (2014) reported that teachers' motivation has a positive, significant effect on teachers' performance. Therefore, teachers' performance must be supported by strong work motivation. That is why it is imperative that elementary school teachers, especially those who have met the requirements according to the law, i.e., having fulfilled academic qualification, should demonstrate high competence, including motivation so that they can improve their performance, which in turn will affect the improvement of student quality.

\section{CONCLUSION}

Based on the research findings and discussion, conclusions can be drawn as follows. (1) Overall, there is no significant average difference between the performance of bachelor degree holder teachers and that of non-degree holder teachers of elementary schools in Kupang, where the significance value of 0.429 is lower than the critical limit of 0.05 . (2) The professional, pedagogic, personal, and social competence of bachelor degree holder teachers is higher than that of non-degree holder teachers of elementary schools in Kupang.

\section{REFERENCES}

Abbas, Y. (2013). Motivasi intrinsik, motivasi ekstrinsik, kompetensi dan kinerja guru. HUMANITAS: Indonesian Psychological Journal, 10(1), 61-74. https://doi.org/10.26555/ humanitas.v10i1.329

Astuti, R., \& Dacholfany, M. I. (2016). Pengaruh supervisi pengawas sekolah dan kepemimpinan kepala sekolah terhadap kinerja guru SMP di Kota Metro Lampung. Jurnal Lentera Pendidikan Pusat Penelitian LPPM UM METRO, 1(2), 204-217. https:// doi.org/10.24127/jlplppm.v1i2.295

Brotosedjati, S. (2012). Pengaruh supervisi kunjungan kelas oleh kepala sekolah dan kompensasi terhadap kinerja guru SD negeri di Kecamatan Sukoharjo. Jurnal Pendidikan Dan Kebudayaan, 18(3), 229-243. https://doi.org/10.24832/jpnk.v18i3.84

Eros, E. (2014). Pengaruh motivasi dan kedisiplinan kerja guru terhadap kinerja guru di SMP negeri Kecamatan Brebes Kabupaten Brebes Jawa Tengah. Jurnal Administrasi Publik Dan Birokrasi, 1(1). http://garuda.ristekbrin.go.id/documents/detail/183090

Inayah, R., Martono, T., \& Sawiji, H. (2013). Pengaruh kompetensi guru, motivasi belajar siswa, dan fasilitas belajar terhadap prestasi belajar mata pelajaran Ekonomi pada siswa kelas XI IPS SMA Negeri 1 Lasem Jawa Tengah tahun pelajaran 2011/2012. Jurnal Pendidikan Insan Mandiri, 2(1), 1-13. https://doi.org/10.20961/iman.v2i1.19638

Indrawati, Y. (2006). Faktor-faktor yang mempengaruhi kinerja guru matematika dalam pelaksanaan Kurikulum Berbasis Kompetensi (KBK) pada Sekolah Menengah Atas Kota Palembang. Jumal Manajemen \& Bisnis Sriwijaya, 4(7), 41-58. http://www. infodiknas.com/wp-content/uploads/2014/11/FAKTOR-FAKTOR-YANG-MEMPE NGARUHI-KINERJA-GURU-MATEMATIKA-DALAM-PELAKSANAAN-KURIK ULUM-BERBASIS-KOMPETENSI-KBK.pdf 
Jeong, D. W., \& Luschei, T. F. (2018). Are teachers losing control of the classroom? Global changes in school governance and teacher responsibilities, 2000-2015. International Journal of Educational Development, 62, 289-301. https://doi.org/10.1016/j.ijedudev. 2018.07.004

Kartowagiran, B. (2011). Kinerja guru profesional (guru pasca sertifikasi). Jurnal Cakerawala Pendidikan, 3(3), 463-473. https://doi.org/10.21831/cp.v3i3.4208

Law No. 14 of 2005 of Republic of Indonesia about Teachers and Lecturers, (2005).

Law of Republic of Indonesia No. 20 of 2003 on National Education System, (2003).

Ministry of Research, Technology, and H. E. of R. of I. (2010). Kerangka kualifikasi nasional Indonesia. Directorate General of Learning and Student Affairs, Ministry of Research, Technology, and Higher Education.

Muthmainnah, S. N., \& Marsigit, M. (2018). Gaya mengajar guru pemula dan guru profesional dalam pembelajaran matematika sekolah menengah pertama. Jurnal Pendidikan Dan Kebudayaan, 3(2), 202-216. https://doi.org/10.24832/jpnk.v3i2.896

Office of Education, Youth, and S. of K. (2010). Profil pendidikan kota Kupang. Office of Education, Youth, and Sport of Kupang.

Pramantik, I. A. D., \& Pardjono, P. (2016). Profesionalisme guru pendidikan khusus di Daerah Istimewa Yogyakarta. Jurnal Akuntabilitas Manajemen Pendidikan, 4(1), 88-100. https:// doi.org/10.21831/amp.v4i1.8200

Regulation of the Minister of National Education No. 16 of 2007, on the Standard of Teachers' Academic Qualification and Competence, (2007).

Regulation of the Minister of National Education No. 19 of 2005, on National Standard of Education, (2005).

Robbins, P. S. (2001). Perilaku organisasi (B. Molan (trans.)). Prentice Hall International.

Sabon, S. S. (2017). Persepsi siswa terhadap kompetensi guru yang sudah dan belum disertifikasi. Jumal Pendidikan Dan Kebudayaan, 2(1), 55-80. https://doi.org/10.24832/ jpnk.v2i1.454

Setyono, H., \& Sudjadi, A. (2011). Pengaruh kompetensi guru, insentif dan lingkungan kerja fisik terhadap guru SMA Negeri 1 Patimuan Kabupaten Cilacap. Sainteks, 8(2), 90-101. https://doi.org/10.30595/sainteks.v8i2.316

Sujarweni, V. W. (2014). SPSS untuk penelitian. Pustaka Baru Press.

Susanto, H. (2012). Faktor-faktor yang mempengaruhi kinerja guru sekolah menengah kejuruan. Jurnal Pendidikan Vokasi, 2(2), 197-212. https://doi.org/10.21831/jpv.v2i2. 1028

Tao, S. (2013). Why are teachers absent? Utilising the Capability Approach and Critical Realism to explain teacher performance in Tanzania. International Journal of Educational Development, 33(1), 2-14. https://doi.org/10.1016/j.ijedudev.2012.01.003 